\title{
Growth and population dynamics of Posidonia oceanica on the Spanish Mediterranean coast: elucidating seagrass decline
}

\author{
Núria Marbà ${ }^{1, *}$, Carlos M. Duarte $^{1}$, Just Cebrián ${ }^{1}$, Margarita E. Gallegos $^{2}$, \\ Birgit Olesen $^{3}$, Kaj Sand-Jensen ${ }^{4}$ \\ ${ }^{1}$ Centre d'Estudis Avançats de Blanes, C.S.I.C., Camí de Santa Bàrbara s/n, E-17300 Blanes, Girona, Spain \\ ${ }^{2}$ Departamento de Hidrobiología, Universidad Autónoma Metropolitana- Iztapalapa, Michocán y Purísima, col. Vicentina, \\ AP 55-535, 09340 México D.F., Mexico \\ ${ }^{3}$ Department of Plant Ecology, University of Aarhus, Nordlandsvej 68, DK-8240 Risskov, Denmark \\ ${ }^{4}$ Freshwater Biological Laboratory, University of Copenhagen, 51 Helsingorsgade, DK-3400 Hillerød, Denmark
}

\begin{abstract}
The growth and population dynamics of Posidonia oceanica were examined in 29 meadows along $1000 \mathrm{~km}$ of the Spanish Mediterranean coast (from $36^{\circ} 46^{\prime}$ to $42^{\circ} 22^{\prime} \mathrm{N}$ ). P. oceanica developed the densest meadows (1141 shoots $\left.\mathrm{m}^{-2}\right)$ and the highest aboveground biomass $\left(1400 \mathrm{~g} \mathrm{DW} \mathrm{m}^{-2}\right)$ between 38 and $39^{\circ}$ N. P. oceanica shoots produced, on average, 1 leaf every $47 \mathrm{~d}$, though leaf formation rates in the populations increased from north to south (range 5.7 to 8.9 leaves shoot ${ }^{-1} \mathrm{yr}^{-1}$ ). $P$. oceanica is a long-living seagrass, with shoots able to live for at least $30 \mathrm{yr}$. P. oceanica recruited shoots at low rates $\left(0.02\right.$ to $0.5 \mathrm{ln}$ units $\left.\mathrm{yr}^{-1}\right)$ which did not balance the mortality rates $\left(0.06\right.$ to $0.5 \mathrm{ln}$ units $\left.\mathrm{yr}^{-1}\right)$ found in most $(57 \%)$ of the meadows. If the present disturbance and rate of decline are maintained, shoot density is predicted to decline by $50 \%$ over the coming 2 to 24 yr. Because $P$. oceanica rhizomes grow very slowly ( 1 to $6 \mathrm{~cm} \mathrm{yr}^{-1}$ apex ${ }^{-1}$ ), maintenance of existing meadows is essential, and our results suggest bad future prospects for $P$. oceanica in the Spanish Mediterranean Sea like most other seagrass species in the world oceans.
\end{abstract}

KEY WORDS: Leaf growth · Rhizome growth - Shoot demography · Posidonia oceanica - Seagrass decline

\section{INTRODUCTION}

Posidonia oceanica (L.) Delile is the dominant seagrass in the Mediterranean Sea, to which it is confined (den Hartog 1970). P. oceanica is a slow-growing climax species (Duarte 1991), which develops large stable meadows, some of which have been dated to be older than 6000 yr (Picard 1965). There is evidence that $P$. oceanica meadows are declining in many regions (e.g. Ardizzone \& Pelusi 1984, Blanc \& Jeudy de Grissac 1984, Porcher 1984, Benedito et al. 1990, SanchezLizaso et al. 1990, Torres et al. 1990, Zavodnik \& Jaklin 1990). The perceived decline of $P$. oceanica has been

\footnotetext{
- Present address: Centre for Estuarine and Coastal Ecology (N.I.O.O.), Vierstraat 28, 4401 EA Yerseke, The Netherlands. E-mail:marba@cemo.nioo.knaw.nl
}

attributed to natural causes e.g. passage of strong storms, Labyrinthula infections, rise in sea level, temperature increase (Blanc \& Jeudy de Grissac 1984, Perès 1984, Bourcier 1989) and anthropogenic disturbances e.g. constructions along the shore-line, trawling fisheries, eutrophication (Perès 1984, Bourcier 1989, Sanchez-Lizaso et al. 1990). Perès (1984) even suggested the observed decline of local $P$. oceanica is part of a large-scale die-off, which could eventually decimate this seagrass species in the Mediterranean Sea. However, the lack of long-term observations of $P$. oceanica meadows and, more important, the limited number of localities examined, prevent a reliable assessment of the magnitude of $P$. oceanica decline in the Mediterranean Sea.

The recent development of techniques to reconstruct past seagrass dynamics (Duarte et al. 1994) allows the 
rapid assessment of seagrass dynamics, at annual time scales, across widespread geographical areas. The reconstruction techniques allow examination of the growth of different seagrass modules (leaves, shoots, rhizomes), which is indicative of the vigour of the plant. Further, these techniques offer a powerful tool to evaluate the decline or the expansion of seagrass populations by examining the balance between shoot recruitment and shoot mortality rates, and thus forecast meadow development (Duarte \& Sand-Jensen 1990, Duarte et al. 1994). Reconstruction techniques have been successfully used to elucidate population dynamics of Cymodocea nodosa (Duarte \& Sand-Jensen 1990), Thalassia testudinum (Gallegos et al. 1993, Durako 1994), Syringodium filiforme (Gallegos et al. 1994), and Halodule wrightii (Gallegos et al. 1994) and they should allow the examination of the growth and population dynamics of $P$. ocednica over large spatial scales.

Here we study the growth (i.e. leaves and rhizomes) and shoot demography of Posidonia oceanica (L.) Delile in 29 meadows distributed along the Spanish Mediterranean coast. The area examined includes populations around an important biogeographic boundary of $P$. oceanica, the Almeria-Oran Front (Fig. 1C), which separates Atlantic surface waters from Mediterranean surface waters. This study provides an evaluation of the status of $P$. oceanica along the Spanish Mediterranean coastline and a test of the postulated widespread decline of this species.

\section{METHODS}

Study area. The 29 Posidonia oceanica meadows examined were located between $36^{\circ} 41^{\prime}$ and $42^{\circ} 22^{\prime} \mathrm{N}$ along the Spanish Mediterranean coast, although only 1 meadow was sampled in the middle part of the range (Fig. 1). This latitudinal gradient involved significant differences in climate, with air and surface seawater temperature increasing by about 6 and $3^{\circ} \mathrm{C}$. respectively, from the northern to the southern range, and an abrupt 2 to $3^{\circ} \mathrm{C}$ drop in sea water temperature in the Atlantic waters west of the Almeria-Oran Front (Lautensach 1967) There is also an important difference in the magnitude and timing of rainfall, and the associated input of terrestrial material along the coastline. The southern range of the study area is characterised by an extreme aridity, with about 9 dry months per year, compared to only
1 to 3 months in the northern part (Lautensach 1967). Similarly, precipitation patterns of dry and wet years also differ between the northern and southern ranges (Temez-Peláez 1993). Moreover, incoming irradiance per year increases by about 30 to $50 \%$ from the north to the south (Lautensach 1967).

The most extensive meadows were located in the south, where the coastline sloped gently into the sea. The meadows at the northern range were smaller, or patchy, because they were on steep shores with frequent rocky outcrops. Three sparse, patchy populations were found west of the Almeria-Oran Front (Gata
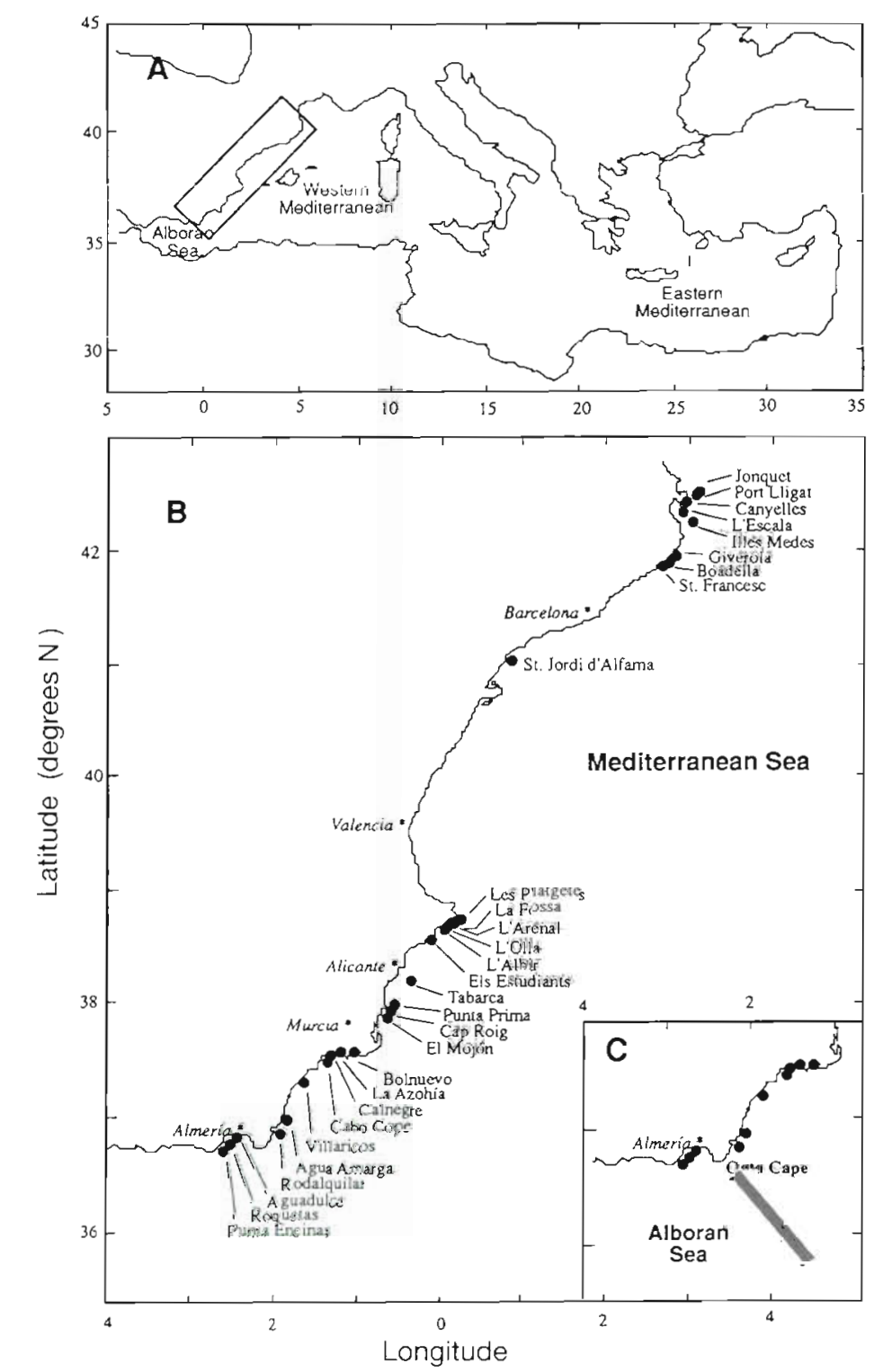

Fig. 1 (A) Study area in the Mediterranean Sea; (B) location of the Posidonia oceanica meadows examined along the Spanish coast; and (C) detailed location of the biogeographical boundary around the Almeria-Oran Front (grey polygon) 
Cape), which is the biogeographical limit of Posidonia oceanica in the Iberian Peninsula (den Hartog 1970. Templado 1984). The front extending from Gata Cape towards Oran separates the Western Mediterranean Surface Waters (WMED) from those in the Alboran Sea, with surface waters dominated by the North Atlantic water mass (NAW) entering through the Straits of Gibraltar (Hopkins 1985). These 2 water masses differ greatly, the NAW being richer in nutrients, less salty and cooler than the WMED (Hopkins 1985). The permanent front that separates these water masses acts as a barrier to the dispersal of propagules of many Mediterranean species to the coastal zone west of the Gata Cape, forming an important biogeographical boundary (García-Raso et al. 1992).

The 29 Posidonia oceanica meadows studied were sampled at the depth of maximum shoot density (typically between 5 and $10 \mathrm{~m}$ depth) during July 1991 (14 populations) and July 1992 (15 populations), the time of maximum aboveground biomass (e.g. RomeroMartinego 1985). In the inner part of each meadow and within about $50 \mathrm{~m}^{2}$, divers harvested between 50 and 100 living vertical short shoots all connected to 15 to 50 horizontal rhizome pieces. In 18 of the populations divers also measured shoot density within triplicate $0.25 \mathrm{~m}^{2}$ quadrats. The plant material collected was transported to the laboratory for morphological measurements (i.e. leaf length, number of standing leaves, vertical rhizome length, number of horizontal internodes and the length of horizontal rhizome between consecutive short shoots), estimation of shoot dry weight after overnight desiccation at $85^{\circ} \mathrm{C}$, and examination of the age structure of living shoots. These measurements allowed estimations of shoot density and aboveground biomass, module size, leaf production, horizontal rhizome growth, leaf and shoot age, shoot recruitment and mortality rates and population halflife (Duarte et al. 1994). Aboveground biomass was derived from the product of shoot density and shoot dry weight.

The average annual leaf formation rate of the shoots (i.e. the number of leaves produced per shoot and year) was estimated from the seasonal signals imprinted on the sheaths and vertical internodes of Posidonia oceanica shoots harvested in each meadow. Leaf formation rate of the populations sampled in 1991 was derived from the seasonal variability in sheath thickness according to Pergent \& Pergent-Martini (1991). Leaf formation rate of the populations sampled in 1992 was estimated from the seasonal variability in vertical internodal length, in the 5 to 10 oldest living shoots collected, following the procedures described in Duarte et di. (1994). The average annuai leat tormation rate of the shoots in each site, therefore, was calculated from 16 to 290 estimates of annual leaf formation from 1968
Table 1. Posidonia oceanica. Validation of the estimates of the average leaf formation rate calculated from changes in the length of the vertical internodes. Mean $( \pm$ SE) number of leaves produced by shoots in 1991 in Illes Medes and in PortLligat, and during 1992 in Jonquet, are estimated using reconstruction techniques and leaf marking techniques

\begin{tabular}{|lccc|}
\hline Meadow & Year & $\begin{array}{c}\text { No. of leaves } \\
\text { shoot }{ }^{-1} \mathrm{yr}^{-1} \\
\text { (reconstruction } \\
\text { techniques) }\end{array}$ & $\begin{array}{c}\text { No. of leaves } \\
\text { shoot }{ }^{-1} \mathrm{yr}^{-1} \\
\text { (leaf marking } \\
\text { techniques) }\end{array}$ \\
\hline $\begin{array}{l}\text { Illes Medes } \\
\text { Port-Lligat }\end{array}$ & 1991 & $9.33( \pm 0.71)$ & $10^{\mathrm{d}}$ \\
Jonquet & 1991 & $5.57( \pm 0.81)$ & $5.17^{\mathrm{cl}}$ \\
& $7.3( \pm 0.75)$ & $7.42^{\mathrm{b}}$ \\
aData from Alcoverro et al. (1995) & \\
'Data from Marbà et al. (1996)
\end{tabular}

to 1992 , depending on the life span of the living shoots harvested. Comparison of the estimates of the annual number of leaves produced per shoot for $3 P$. oceanica sampled here, concurrent with assessment using leaf marking techniques (Table 1), demonstrated an excellent agreement between both estimates. These results further validate the estimates of annual leaf production, from which the average duration of a plastochron interval (P.I.) is derived, obtained using reconstruction techniques (Duarte et al. 1994), Knowledge of the average number of leaves produced annually per shoot in each meadow during the shoot life span allowed calculation of the annual average leaf P.I. (the time elapsed between the formation of 2 consecutive leaves; Erikson \& Michellini 1957), and, in turn, translation of time in P.I. to absolute time (i.e. days or years). We estimated leaf turnover rate as the average number of leaves produced annually per shoot in each meadow divided by the average number of standing leaves during the sampling time. We used the equations described in Cebrián et al. (1995) to estimate the age of the leaves, and, subsequently, we calculated the median leaf age (i.e. leaf longevity) in each population.

The rate of formation of horizontal rhizome internodes was estimated by regressing the number of horizontal internodes between pairs of shoots connected by a horizontal rhizome piece against their age difference (Duarte et al. 1994). The regression slope represented the average number of rhizome internodes produced per leaf P.I. Once the leaf P.I. is translated into days, the inverse of this slope equals the time the plant spends to produce a horizontal rhizome internode (i.e. rhizome P.I.). The product of this slope, the average length of a rhizome internode and the average annual rate of leaf formation, provided an estimate of the average annual horizontal rhizome elongation rate (Duarte et al. 1994). 
The population dynamics of the meadow was characterised by the age distribution of living shoots, shoot recruitment, shoot mortality, and net population growth rates (cf Duarte et al. 1994). Shoot age was estimated as the product of the total number of leaves produced during the shoot life-span (i.e. number of standing leaves plus leaf sheaths from shed leaves = number of P.I.s) multiplied by the leaf P.I. The annual gross shoot recruitment rate $\left(R_{\text {gross, }}\right.$ ln units $\left.\mathrm{yr}^{-1}\right)$ was calculated as

$$
R_{\text {gross }}=\ln \sum_{t=0}^{\infty} N_{t}-\ln \sum_{t=1}^{\infty} N_{t}
$$

where $\sum_{t=0}^{\infty} N_{t}$ is the number of living shoots and $\sum_{t=1}^{\infty} N_{t}$ is the number of living shoots $>1 \mathrm{yr}$. Shoot mortality rate $\left(M\right.$, In units $\left.y r^{-1}\right)$ was derived from the exponential decline in the abundance of living shoots $\left(N_{0}\right)$ with time $(t$, in P.I.s) as (e.g. Sheil et al. 1995)

$$
N_{t}=N_{0} \cdot e^{-M \cdot t}
$$

where $N_{0}$ is the number of shoots with age equal to the mode, $N_{t}$ is the number of shoots older than the modal age at time $t$, and $M$ is the mortality rate (In units P..$^{-1}$ ). The shoot mortality rate $(M)$ was estimated using a semilogarithmic linear regression model, where we assumed constant mortality over shoot age classes and years. We were unable to estimate mortality rates from distributions of shoot age-at-death because of the small number of dead shoots harvested. Thus, the mortality rates estimated here may be slightly altered by interannual fluctuations in shoot recruitment and mortality during shoot life-span (Duarte et al. 1994). The ratio between recruitment and mortality rates (R:M) was used to indicate whether populations were expanding (i.e. $R: M>1$ ), declining (i.e. $R: M<1$ ) or in steady state (i.e. $R: M=1$; Duarte \& Sand-Jensen 1990, Duarte et al. 1994). We used the net rate of shoot population growth $\left(R_{\text {net }}=R_{\text {gross }}-M_{i}\right.$ Duarte et al. 1994) to forecast the future development of the meadows.

Growth and demographic variables were calculated for a parcel of about $50 \mathrm{~m}^{2}$ sampled in each meadow (i.e. the sampling unit of this study), and its variability was examined over a spatial scale of $1000 \mathrm{~km}$ of coastline across 7 degrees of latitude. The importance of variability in meadow properties at large ( $>1$ degree latitude) and local scale ( $<1$ degree latitude) was examined using analysis of variance and Tukey multiple comparisons test. Pearson correlation coefficients and least square linear regression analyses were used to describe the relationships between the variables. Variables were log-transformed when necessary to comply with the requirements of the statistical analyses. Significant differences in shoot mortality and recruitment rates were tested using a $t$-test on the parameters and their standard error. We used the coefficient of variation to compare the relative amounts of plasticity of the different parameters of plant dynamics.

\section{RESULTS}

Posidonia oceanica shoot density ranged between 78 and 1411 shoots $\mathrm{m}^{-2}$. The densest meadows were located between 38 and $39^{\circ} \mathrm{N}$ and the sparsest meadows were in the north (Fig. 2, Tukey analysis, $\mathrm{p}<0.05$ ). The slight decline in shoot density west of the Gata

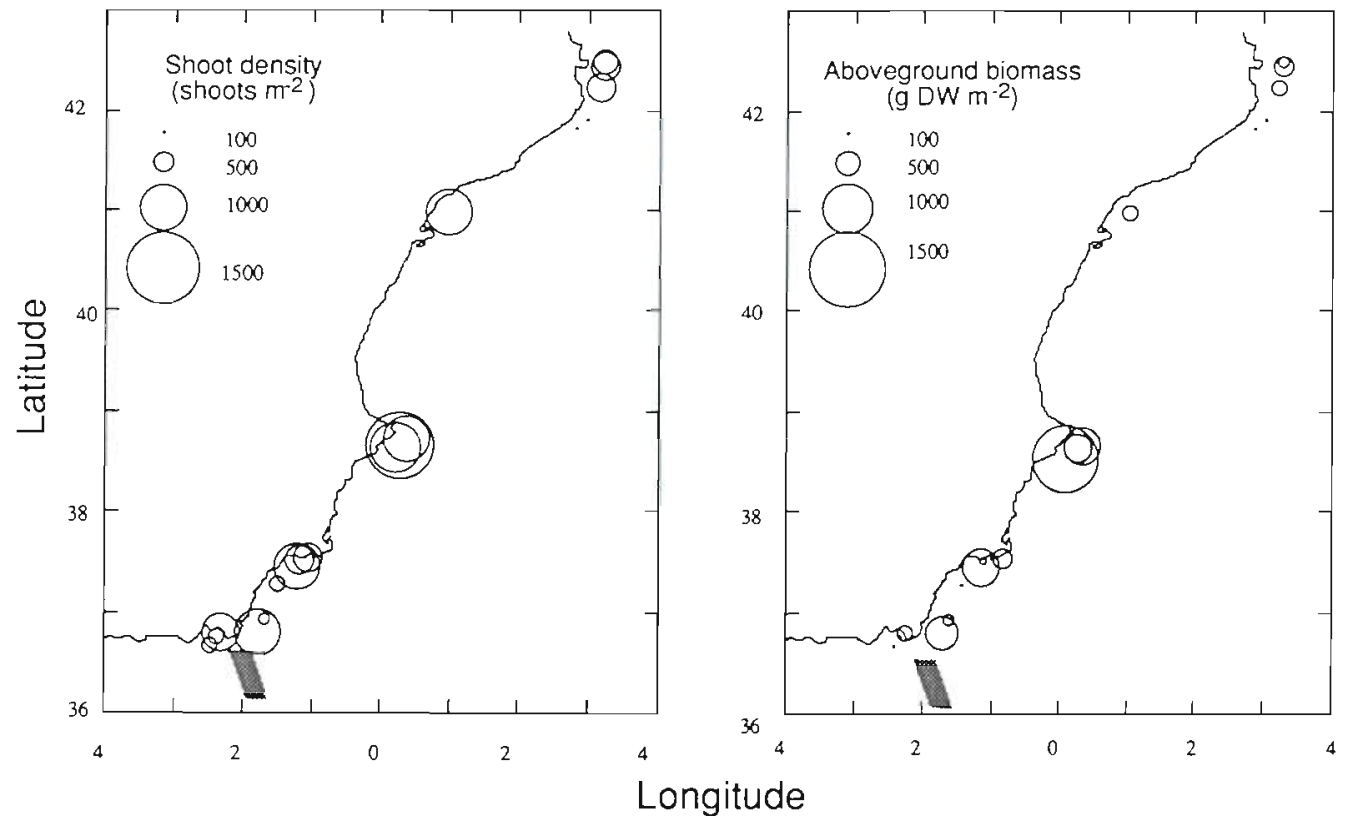

Fig. 2. Posidonia oceanica. Spatial variabiluty of shoot density and aboveground biomass. Grey polygon locates the Almeria-Oran Front 
Table 2. Posidonia oceanica. Basic morphological and dynamic features in the 29 meadows studied from north to south along the Spanish Mediterranean coast (mean values \pm SE). The bottom rows present the results of ANOVA for each variable to test large (among degree of latitude) or small (within degree of latitude) spatial scale variability, and the coefficient of variation [i.e. (SD $\times$ $100) /$ mean]. P.I: plastochron interval; P/B: leaf turnover rate; nd: no data; ns: not significant $(p>0.05)$ analysis

\begin{tabular}{|c|c|c|c|c|c|c|c|c|c|}
\hline Population & $\begin{array}{l}\text { Shoot } \\
\text { size } \\
\text { W shoot }\end{array}$ & $\begin{array}{c}\text { Leaf } \\
\text { length } \\
(\mathrm{cm})\end{array}$ & $\begin{array}{l}\text { No. of stand- } \\
\text { ing leaves } \\
\left(\text { shoot }^{-1}\right)\end{array}$ & $\begin{array}{l}\text { No. of leaves } \\
\text { produced } \\
\left(\text { shoot }^{-1} \mathrm{Yr}^{-1}\right)\end{array}$ & $\begin{array}{l}\text { Leaf } \\
\text { P.l. } \\
\text { (d) }\end{array}$ & $\begin{array}{l}\text { Leaf } \\
\mathrm{P} / \mathrm{B} \\
\left(\mathrm{yr}^{-1}\right)\end{array}$ & $\begin{array}{l}\text { Rhizome } \\
\text { P.I. } \\
\text { (d) }\end{array}$ & $\begin{array}{l}\text { Leaf } \\
\text { production } \\
\left(g \text { DW shoot }{ }^{-1} \mathrm{Yr}^{-1}\right)\end{array}$ & $\begin{array}{c}\text { Rhizome } \\
\text { elongation } \\
\left(\mathrm{cm} \mathrm{rhiz}^{-1} \mathrm{yr}^{-1}\right)\end{array}$ \\
\hline Jonquet & 0.564 & $27.9 \pm 1.5$ & $4.3 \pm 0.2$ & $7.1 \pm 0.2$ & 51.4 & 1.65 & 35.9 & 0.925 & 2.0 \\
\hline Port Lligat & 0.678 & nd & $5 \pm 0.3$ & $5.3 \pm 0.2$ & 68.9 & 1.06 & 65.0 & 0.627 & 2.0 \\
\hline Canyelles & 0.627 & $35.7 \pm 1.4$ & $5.5 \pm 0.1$ & $7.6 \pm 0.3$ & 48.0 & 1.38 & 48.5 & 0.859 & 1.9 \\
\hline L'Escala & 1.323 & $34.2 \pm 1.7$ & $4.2 \pm 0.1$ & $7.3 \pm 0.3$ & 50.0 & 1.74 & 72.5 & 2.278 & 1.2 \\
\hline Illes Medes & 0.576 & $21.5 \pm 0.8$ & $5.5 \pm 0.2$ & $7.8 \pm 0.2$ & 46.8 & 1.42 & 51.4 & 0.812 & 2.0 \\
\hline Giverola & 0.571 & $25.5 \pm 1.3$ & $5.9 \pm 0.1$ & $7.5 \pm 0.1$ & 48.7 & 1.27 & 54.7 & 0.721 & 2.1 \\
\hline Boadella & 0.516 & $21.7 \pm 1$ & $6.1 \pm 0.5$ & $7.5 \pm 0.1$ & 48.7 & 1.23 & 30.6 & 0.628 & 3.7 \\
\hline St. Francesc & 0.650 & $24.4 \pm 1.1$ & $6 \pm 0.2$ & $7.5 \pm 0.2$ & 48.7 & 1.25 & 45.1 & 0.815 & 2.4 \\
\hline St. Jordi d'Alfama ${ }^{d}$ & 0.411 & $17.7 \pm 0.8$ & $4.7 \pm 0.1$ & $8.9 \pm 0.3$ & 41.0 & 1.89 & 37.6 & 0.785 & 2.6 \\
\hline Les Platgetes & 0.715 & $39.4 \pm 2.7$ & $5.1 \pm 0.1$ & $6.7 \pm 0.1$ & 54.5 & 1.31 & 74.6 & 0.935 & 1.7 \\
\hline La Fosia & 0.553 & $39.4 \pm 1.71$ & $4.7 \pm 0.1$ & $7 \pm 0.1$ & 52.1 & 1.49 & 35.7 & 0.821 & 3.9 \\
\hline L'Arenal & 1.281 & $38.3 \pm 1.7$ & $4.6 \pm 0.1$ & $7.8 \pm 0.1$ & 46.8 & 1.70 & 42.2 & 2.171 & 1.7 \\
\hline L'Olla & 0.578 & $37.9 \pm 2.6$ & $4.1 \pm 0.1$ & $5.8 \pm 0.1$ & 62.9 & 1.41 & nd & 0.821 & nd \\
\hline L'Albir & 0.216 & $20.7 \pm 1.7$ & $3.7 \pm 0.1$ & $6.7 \pm 0.1$ & 54.5 & 1.81 & 66.4 & 0.386 & 1.0 \\
\hline Els Estudiants & 1.268 & $46.2 \pm 1.8$ & $4.3 \pm 0.1$ & $8.5 \pm 0.1$ & 42.9 & 1.98 & 34.9 & 2.495 & 2.4 \\
\hline Tabarca & 0.450 & $24.8 \pm 2.80$ & $3.5 \pm 0.1$ & $7.3 \pm 0.4$ & 50.0 & 2.09 & 53.8 & 0.926 & 1.6 \\
\hline Punta Prima & 1.323 & $41.8 \pm 1.63$ & $4.7 \pm 0.1$ & $6.8 \pm 0.1$ & 53.7 & 1.45 & 49.7 & 1.898 & 2.8 \\
\hline Cap Roig & 0.629 & $41.1 \pm 2.9$ & $4.1 \pm 0.1$ & $8 \pm 0.1$ & 45.6 & 1.95 & 37.1 & 1.218 & 2.1 \\
\hline El Mojón & 0.824 & $21.3 \pm 1.2$ & $4.6 \pm 0.1$ & $6.6 \pm 0.1$ & 55.3 & 1.43 & 50.3 & 1.181 & 1.2 \\
\hline Bolnuevo & 0.510 & $35.6 \pm 1.7$ & $4.1 \pm 0.2$ & $8.1 \pm 0.7$ & 45.1 & 1.98 & 41.0 & 1.003 & 2.7 \\
\hline La Azohía & 0.185 & $14 \pm 1.1$ & $4.2 \pm 0.1$ & $8.5 \pm 0.3$ & 42.9 & 2.02 & 34.9 & 0.371 & 2.0 \\
\hline Calnegre & 0.285 & $25.4 \pm 2$ & $3.9 \pm 0.2$ & $7.5 \pm 0.3$ & 48.7 & 1.92 & 45.5 & 0.542 & 2.1 \\
\hline Cabo Cope & 0.797 & $27.3 \pm 1.6$ & $4.8 \pm 0.2$ & $8.4 \pm 0.3$ & 43.5 & 1.75 & 24.3 & 1.407 & 5.9 \\
\hline Villaricos & 0.279 & $22.4 \pm 0.8$ & $5.7 \pm 0.2$ & $8.9 \pm 0.6$ & 41.0 & 1.56 & 30.8 & 0.438 & 3.0 \\
\hline Agua Amarga & 0.944 & $51.7 \pm 3.4$ & $4.1 \pm 0.1$ & $8.4 \pm 0.3$ & 43.5 & 2.05 & 33.9 & 1.939 & 3.2 \\
\hline Rodalquilar & 0.729 & $41.8 \pm 1.8$ & $3.6 \pm 0.1$ & $8.6 \pm 0.2$ & 42.4 & 2.39 & 47.7 & 1.741 & 3.3 \\
\hline Aguadulce & 0.452 & $35.3 \pm 9.6$ & $4.1 \pm 0.2$ & $8.8 \pm 0.3$ & 41.5 & 2.15 & 52.5 & 0.972 & 1.6 \\
\hline Roquetas & 0.323 & $16.4 \pm 0.8$ & $5.2 \pm 0.2$ & $8.8 \pm 0.3$ & 41.5 & 1.69 & 39.5 & 0.548 & 2.5 \\
\hline Punta Encinas & 0.487 & $19.6 \pm 0.9$ & $5.5 \pm 0.2$ & $8 \pm 0.3$ & 45.6 & 1.45 & 29.2 & 0.715 & 1.8 \\
\hline$\sum x^{2}$ within groups & 2.7 & 22.14 & 8 & 13.6 & 772 & 1.7 & 3447 & 9.0 & 22.9 \\
\hline$\sum x^{2}$ among groups & 0.2 & 512 & 7 & 8.1 & 359 & 1.2 & 1070 & 0.7 & 3.6 \\
\hline df & 4 & 4 & 4 & 4 & 4 & 4 & 4 & 4 & 4 \\
\hline$p$ & ns & ns & 0.01 & 0.05 & 0.05 & 0.01 & ns & ns & ns \\
\hline CV $(\%)$ & 49 & 38 & 15 & 12 & 13 & 24 & 28 & 55 & 42 \\
\hline
\end{tabular}

Cape (Fig. 2) might reflect the inability of $P$. oceanica to develop dense meadows in Atlantic waters (Templado 1984). Fluctuations in shoot density explained most (regression analysis; $R^{2}=0.68$, slope $=0.85 \pm 0.13$, $\mathrm{n}=18, \mathrm{p}<0.0001$ ) of the variability in aboveground biomass along the Spanish Mediterranean coast. Aboveground biomass in the meadows changed about 2 orders of magnitude (Fig. 2), and varied significantly (ANOVA, $\mathrm{p}<0.05$ ) at large spatial scales.

The size of Posidonia oceanica shoots differed up to 7 -fold among populations, but most (ANOVA, Table 2) of this variation was attributable to factors occurring at spatial scales smaller than 1 degree of latitude. Vari- ability in shoot size derived from differences in the number and the size of the standing leaves, with shoots with few leaves supporting longer leaves (Pearson correlation, $r=0.96, n=14, p<0.00001$; Fig. 3 ). The shoots growing in the meadows between 41 and $42^{\circ} \mathrm{N}$ had significantly (Tukey analysis, $\mathrm{p}<0.05$; Table 2) more leaves than those growing south of $39^{\circ} \mathrm{N}$. In contrast, variability in the mean length of the leaves among the meadows was enhanced by local factors (Table 2 ).

The Posidonia oceanica populations produced leaves at very similar rates (Table 2). However, leaf turnover rate $(\mathrm{P} / \mathrm{B})$ declined as the number of leaves per shoot increased (Pearson correlation, $r=-0.78, p<0.001$, 


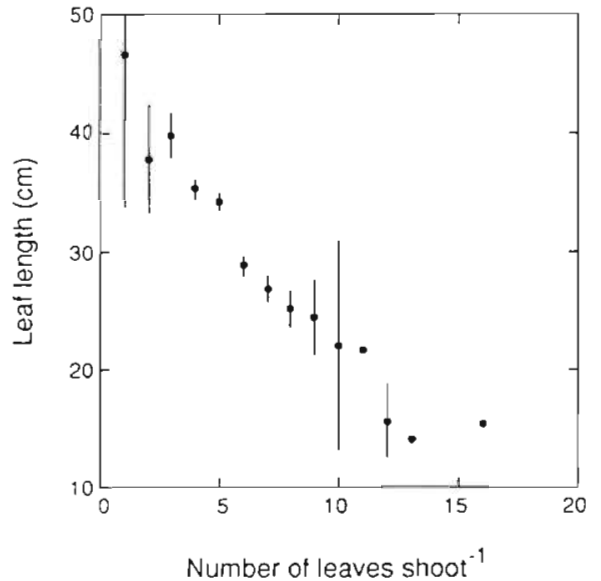

Fig. 3. Relationship between the number of standing leaves on shoots and the average length of the leaves they support. Shoots collected were grouped by the number of leaves they had and then we calculated the average \pm standard error of leaf length

$\mathrm{n}=29_{i}$ Fig. 4A) and as leaf plastochron interval increased (Pearson corrclation, $r=0.60, p<0.001, n=$ 29; Fig. 4B). Moreover, populations with fast-growing leaves (i.e. with short P.I.s) should also shed them faster than slow-growing ones. This coupling was confirmed by the significant negative correlation (Pearson correlation, $\mathrm{r}=-0.40, \mathrm{n}=27, \mathrm{p}<0.05$ ) between leaf turnover and leaf life span (Fig. 4C).

Leaf dynamics (i.e. leaf P.I., P/B) showed significant large-scale variation (ANOVA, Table 2), because leaves tended to have shorter P.I.s and faster turnover in southern meadows. The close relationship between leaf dynamics and static properties (e.g number of leaves shoot ${ }^{-1}$ indicated that the static properties may have considerable diagnostic potential to evaluate leaf growth.

The horizontal rhizome P.I. was similar, and significantly correlated $(r=0.60, n=28, p<0.005)$, to the P.I. of leaves (Table 2). Horizontal rhizome growth rates were very small (Table 2), indicating Posidonia oceanica to be the seagrass species with the slowest clonal growth ever reported (Duarte 1991). Despite the low rates of rhizome growth observed, they changed almost 5-fold among the populations examined. Most of this variability was attributable to factors occurring at local scale (ANOVA, Table 2). These large differences in horizontal rhizome elongation rate of $P$. oceanica suggest that its ability to recover in disturbed meadows varies greatly along the Spanish Mediterranean coast, because this seagrass species basically recovers by spreading its rhizomes across the sediments (Meinesz \& Lefevre 1984)

Shoots of Posidonia oceanica can live for decades. Maximum shoot age ranged between 6 and 30 yr at the different sites (Table 3 ). The age structure of $P$, oceanica shoots showed, in general, a mode of shoots about 2 yr old, and an exponential decline in shoot abundance with greater age due to shoot mortality (Fig. 5; Duarte et al. 1994). Few populations (e.g El Mojón, Fig. 5) showed a modal age $>5 \mathrm{yr}$, which indicates a severe reduction in shoot recruitment over the past few years. The decline in shoot abundance with shoot age did not follow a smooth trend (Fig. 5), suggesting
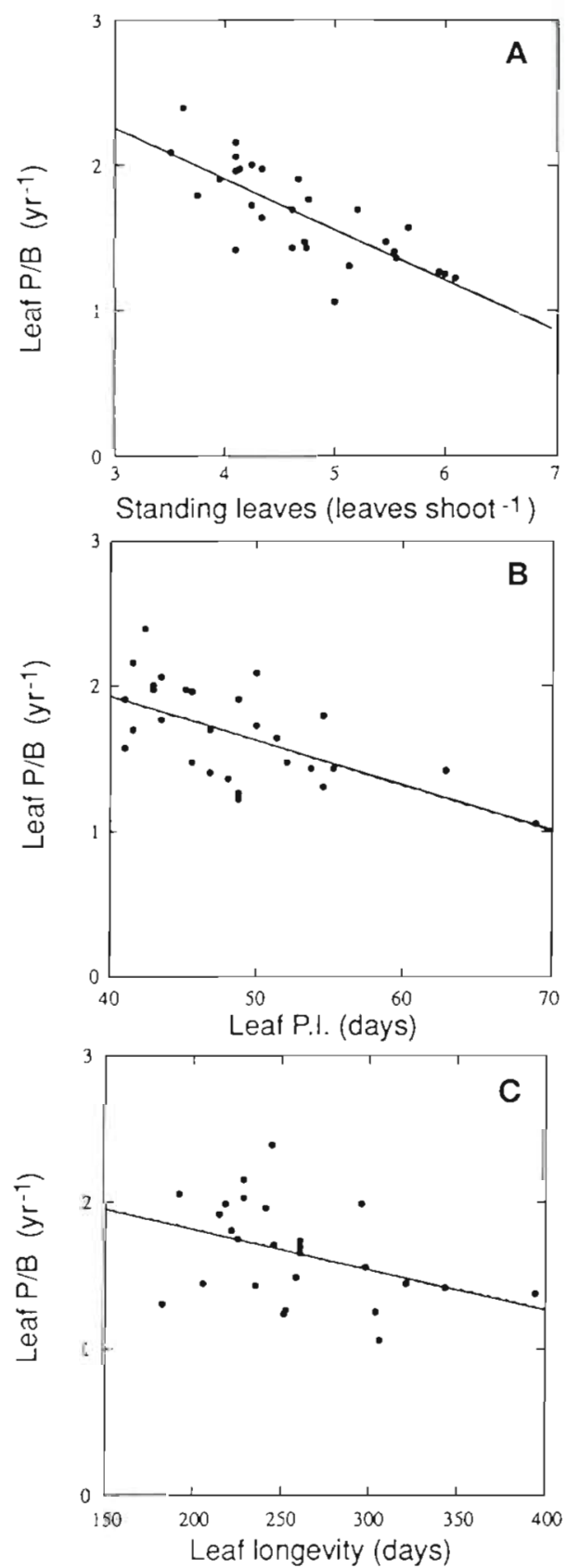

Fig. 4. Posidonia oceanica. Relationship between (A) the number of standing leaves on shoots; (B) leaf plastochron interval; (C) leaf longevity, and leaf $P / B$ (leaf turnover rate) 
Table 3. Posidonia oceanica. Variables used to characterise shoot population dynamics in the 29 meadows studied from north to south along the Spanish Mediterranean coast. The bottom rows present the results of ANOVA for each variable to test large (among degree of latitude) or small (within degree of latitude) spatial scale variability, and the coefficient of variation [j.e. (SD $x$ $100 \mathrm{j} / \mathrm{mean}]$. ns: not significant ( $\mathrm{p}>0.05$ ) analysis

\begin{tabular}{|c|c|c|c|c|c|c|}
\hline Population & $\begin{array}{c}\text { Median } \\
\text { shoot age } \\
(y r)\end{array}$ & $\begin{array}{c}\text { Maximum } \\
\text { shoot age } \\
(y r)\end{array}$ & $\begin{array}{l}\text { Shoot recruit- } \\
\text { ment rate } \\
\left.\text { (ln units } y^{-1}\right)\end{array}$ & $\begin{array}{l}\text { Shoot morta- } \\
\text { lity rate } \\
\left.\text { (ln units } \mathrm{yr}^{-1}\right)\end{array}$ & $\begin{array}{l}\text { Net recruit- } \\
\text { ment rate } \\
\left(\text { ln units } \mathrm{yr}^{-1}\right)\end{array}$ & $\begin{array}{c}\text { Shoot } \\
\text { turnover } \\
\left(y^{r}\right)\end{array}$ \\
\hline Jonquet & 3.5 & 23.4 & 0.10 & $0.07 \pm 0.07$ & $0.029 \mathrm{~ns}$ & 6.9 \\
\hline Port Lligat & 5.7 & 23.0 & 0.04 & $0.18 \pm 0.02$ & -0.13 & 17.3 \\
\hline Canyelles & 3.9 & 8.8 & 0.13 & $0.23 \pm 0.08$ & $-0.1 \mathrm{~ns}$ & 5.3 \\
\hline L'Escala & 7.4 & 18.4 & 0.03 & $0.06 \pm 0.04$ & $-0.03 \mathrm{~ns}$ & 23.1 \\
\hline Illes Medes & 5.3 & 22.2 & 0.03 & $0.08 \pm 0.01$ & -0.05 & 23.1 \\
\hline Giverola & 2.4 & 79 & 0.09 & $0.15 \pm 0.08$ & $-0.06 \mathrm{~ns}$ & 7.7 \\
\hline Boadella & 1.5 & 5.2 & 0.16 & $0.45 \pm 0.23$ & $-0.29 \mathrm{~ns}$ & 4.3 \\
\hline St. Francesc & 2.7 & 29.5 & 0.10 & $0.08 \pm 0.01$ & 0.02 & 6.9 \\
\hline St. Jordi d'Alfamad & 2.8 & 24.7 & 0.07 & $0.18 \pm 0.01$ & -0.11 & 9.9 \\
\hline Les Platgetes & 4.6 & 21.5 & 0.02 & $0.07 \pm 0.01$ & -0.05 & 34.6 \\
\hline La Fossa & 2.7 & 21.9 & 0.16 & $0.07 \pm 0.01$ & 0.09 & 4.3 \\
\hline L'Arenal & 4.7 & 10.1 & 0.13 & $0.06 \pm 0.06$ & $0.07 \mathrm{~ns}$ & 5.3 \\
\hline L'Olla & 1.6 & 6.9 & 0.05 & $0.53 \pm 0.22$ & -0.48 & 13.8 \\
\hline L'Albir & 3.4 & 14.5 & 0.07 & $0.20 \pm 0.07$ & -0.13 & 9.9 \\
\hline Els Estudiants & 4.9 & 10.7 & 0.03 & $0.26 \pm 0.09$ & -0.23 & 23.1 \\
\hline Tabarca & 11.2 & 19.9 & - & - & - & - \\
\hline Punta Prima & 7.2 & 11.9 & 0.02 & $0.27 \pm 0.07$ & -0.25 & 34.6 \\
\hline Cap Roig & 3.1 & 14.0 & 0.03 & $0.16 \pm 0.08$ & -0.13 & 23.1 \\
\hline El Mojón & 8.6 & 15.5 & 0.06 & $0.33 \pm 0.05$ & -0.27 & 11.5 \\
\hline Bolnuevo & 2.7 & 14.2 & 0.12 & $0.24 \pm 0.01$ & -0.12 & 5.7 \\
\hline La Azohía & 2.7 & 27.2 & 0.09 & $0.17 \pm 0.01$ & -0.08 & 7.7 \\
\hline Calnegre & 3.5 & 21.9 & 0.10 & $0.15 \pm 0.01$ & -0.05 & 6.9 \\
\hline Cabo Cope & 2.4 & 19.8 & 0.16 & $0.08 \pm 0.01$ & 0.08 & 4.3 \\
\hline Villaricos & 1.8 & 8.3 & 0.40 & $0.45 \pm 0.09$ & $-0.05 \mathrm{~ns}$ & 1.7 \\
\hline A.gua Amarga & 5.8 & 20.2 & 0.11 & $0.08 \pm 0.01$ & 0.03 & 6.3 \\
\hline Rodalquilar & 3.0 & 16.3 & 0.10 & $0.26 \pm 0.01$ & -0.16 & 6.9 \\
\hline Aguadulce & 4.1 & 20.8 & 0.03 & $0.18 \pm 0.01$ & -0.15 & 23.1 \\
\hline Roquetas & 2.6 & 18.9 & 0.10 & $0.18 \pm 0.01$ & -0.08 & 6.9 \\
\hline Punta Encinas & 1.6 & 7.1 & 0.44 & $0.48 \pm 0.08$ & $-0.04 \mathrm{~ns}$ & 1.5 \\
\hline$\sum x^{2}$ within groups & 121 & 1108 & 0.19 & 0.29 & 0.08 & 1238 \\
\hline$\sum x^{2}$ among groups & 23 & 131 & 0.04 & 0.03 & 0.03 & 481 \\
\hline $\mathrm{df}$ & 4 & 4 & 4 & 4 & 4 & 4 \\
\hline $\mathrm{p}$ & ns & ns & ns & ns & ns & ns \\
\hline $\mathrm{CV}(\%)$ & 56 & 39 & 99 & 65 & 147 & 82 \\
\hline
\end{tabular}

important interannual differences in shoot recruitment and mortality rates. Shoot recruitment rates showed important differences among populations. These differences were as important among neighbour populations as among distant ones (ANOVA, Table 3). However, the highest shoot recruitment rates were found in the southern populations (Fig. 6). The estimates of recruitment rate indicate a steady-state turnover time of shoots, and, therefore, rhizomes (Gallegos et al. 1993), ranging from 1.6 to 34.7 yr (Table 3). Shoot mortaility rates differed greatly among the meadows (Fig. 6), basically at $<1$ latitudinal degree scales (Table 3).
Comparison of recruitment and mortality rates for the individual populations showed that mortality exceeded recruitment in $78 \%$ of the meadows, though the differences for the individual populations were only significant in $57 \%$ of the cases ( $t$-test, $p<0.05$, Table 3 ). The net rate of population change (i.e. $R_{\text {gross }}-M$ ) was used to forecast the future development of the meadows. These calculations indicated the time for shoot density to be reduced by $50 \%$ in the 22 declining meadows to range from 2 to $24 \mathrm{yr}$, with an average of $9 \pm 2 \mathrm{yr}$. These results predict widespread decline of Posidonia oceanica in the Spanish coast within the next decade, if present growth conditions are maintained. 


\section{DISCUSSION}

The results demonstrate substantial plasticity in Posidonia oceanica growth and population dynamics along the Spanish Mediterranean coast. Growth plasticity was derived mainly from differences in module size, whereas the rates at which the modules were added were rather similar among the populations (Table 2). The low variability of the P.I. of modules demonstrates these to be under tight control as part as the growth programme of $P$. oceanica, and to be little influenced by the particular conditions in each population.

The plasticity observed in Posidonia oceanica module size and dynamics was expressed both at large $1>1$ latitudinal degree) and at local scale (i.e. $<1$ latitudinal degree, Tables $2 \& 3$ ). Large-scale heterogeneity of $P$. oceanica dynamics reflected variability in the climate they experience along the Spanish Mediterranean coast. Light availability and surface water temperature
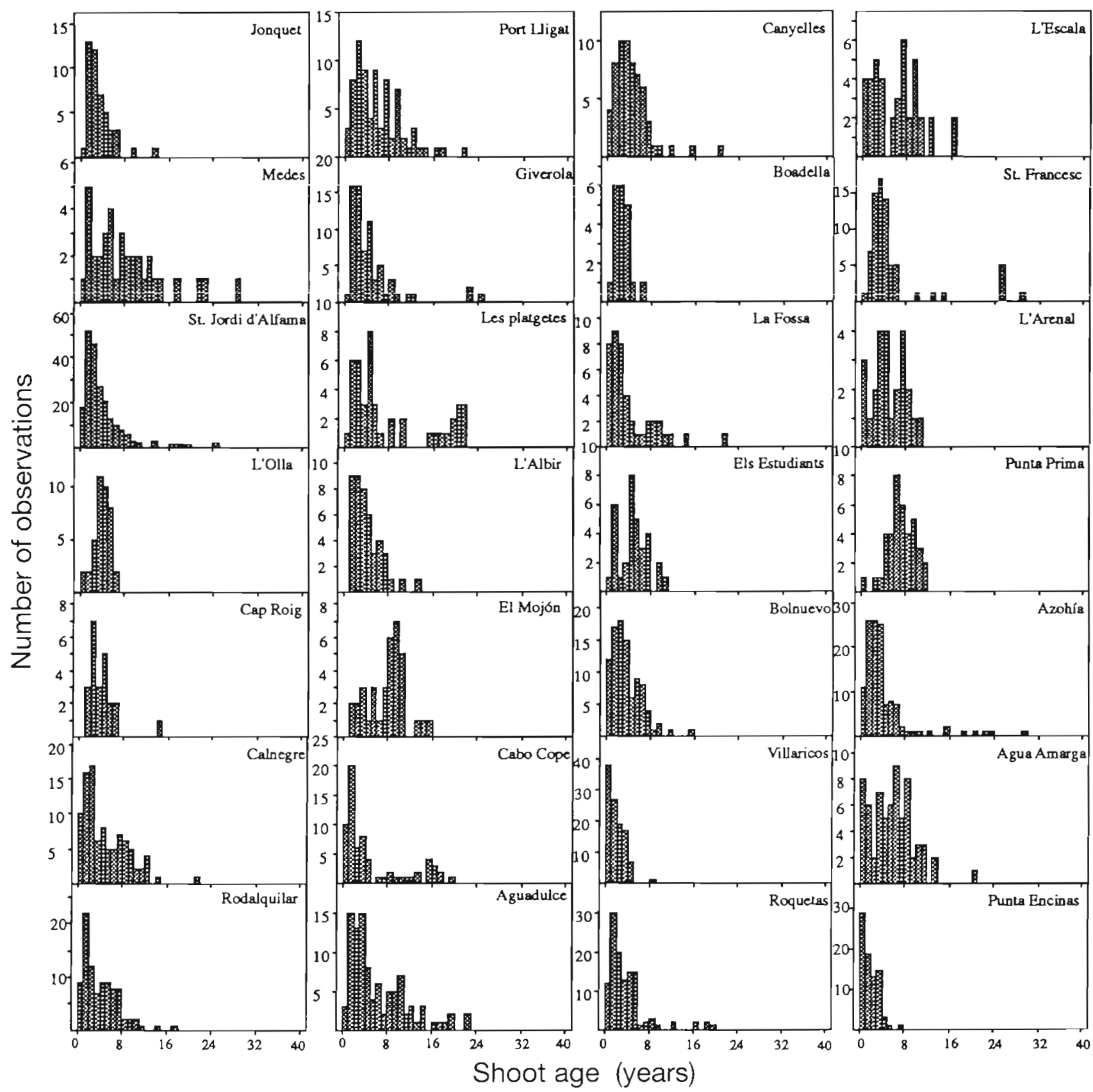

Fig. 5. Posidonia oceanica. Shoot age structure of living shoots of each population 

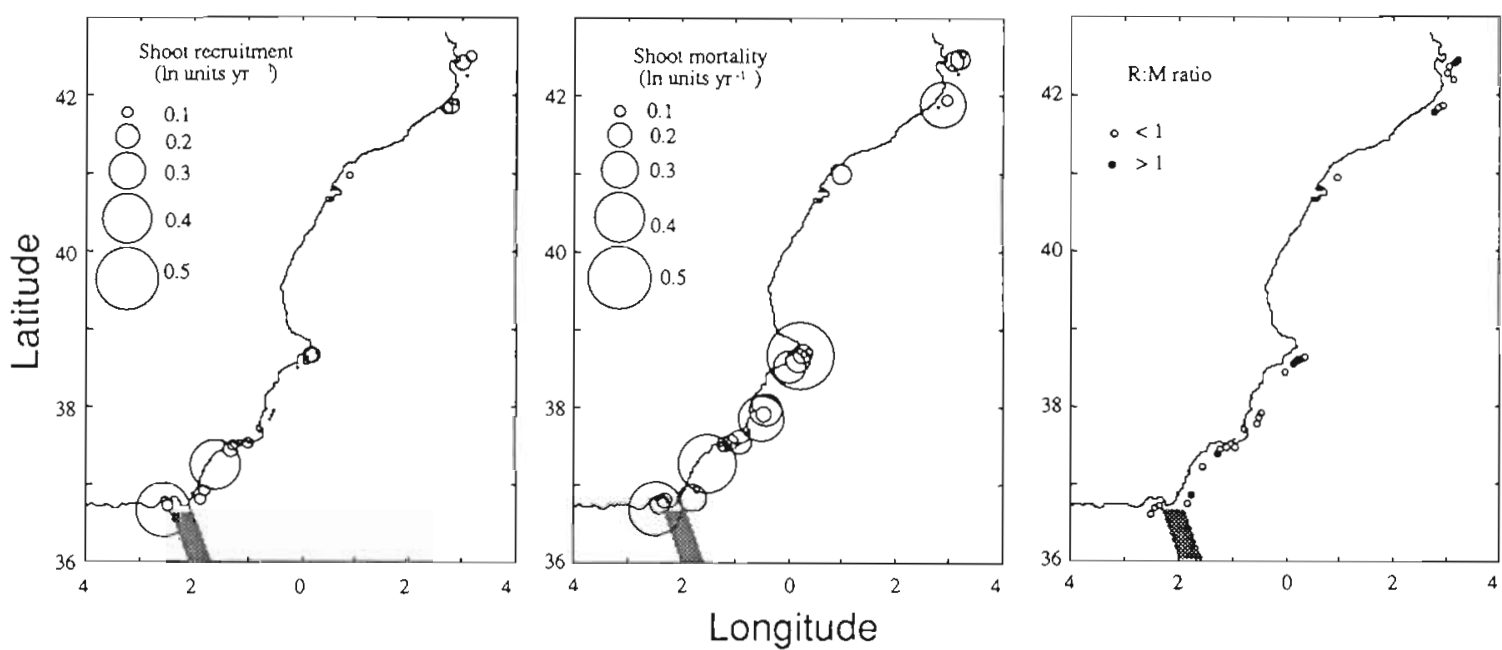

Fig. 6. Posidonia oceanica. Spatial variability of shoot recruitment, shoot mortality and meadow colonisation state (i.e. regression, expansion or steady state: $R: M<1, R: M>1$ or $R: M=1$, respectively). Grey polygon locates the Almeria-Oran Front. Note that the diameter of the circles in shoot recruitment and mortality is a continuous variable and the scale shows some sizes as a reference

increase to the south, and are associated with a parallel increase in leaf turnover, leaf size, and leaf production rate, as well as higher shoot recruitment rates, allowing denser, more productive meadows to develop. The latitudinal constraints on seagrass meadow development have been suggested in the past when differences in lushness of beds of Thalassia testudinum, Syringodium filiforme and Halodule wrightii in Chandeleur Sound (Louisiana) were compared with those about $50 \mathrm{~km}$ to the north (Eleuterious 1987). The spatial distribution of water masses in the Mediterranean Sea also contributes to large-scale heterogeneity in water temperature. The North Atlantic Water mass (NAW) dominates the surface waters in the Alboran Sea (Hopkins 1985), and is cooler than the Western Mediterranean Surface Water mass (WMED). Accordingly, populations growing west of the Almeria-Oran Front developed shoots with shorter and longer living leaves relative to those expected from their latitudinal location.

The Posidonia oceanica populations growing at the biogeographical boundary in the south developed sparse meadows with relatively low aboveground biomass (Fig. 2), when compared with meadows $100 \mathrm{~km}$ further north. However, the shoot biomass and density supported by these meadows were similar to those supported by meadows in the northern range of the study and populations examined in the past (e.g. Ischia, Pergent 1990; Algeria, Semoroud et al. 1990). The meadow studied furthest into the Alboran Sea (Punta Encinas) showed a low maximal shoot age, and the $y$ oungest ñüual aye (Fig. 5), suggesing that shoot mortality starts to operate earlier at the biogeographical boundary of the species.
Our results suggest a general decline of Posidonia oceanica meadows in the Spanish Mediterranean, because $78 \%$ of the populations tended to decline in shoot density. The forecasted decline of meadows resulted from a combination of increased mortality rates and reduced recruitment rates, which may result in a decline of cover of the meadows. For instance, the age structure of shoots sampled at El Mojón showed evidence of a substantial reduction in recruitment rate over the last 5 yr or so, as well as high mortality rate (Fig. 5). A field trip 3 yr later revealed a virtual total demise of this population, with only a few scattered clumps of shoots left of a lush population extending several $\mathrm{km}^{2} 3$ yr earlier. This rapid loss occurred much earlier than expected from the demographic data, which predicted the shoot population to decline by $60 \%$ over the $3 \mathrm{yr}$. This very rapid decline is perhaps associated with the construction of a raw sewage outlet near the meadow 1 yr before sampling, which has exacerbated existing eutrophication problems. The widespread decline of $P$. oceanica meadows in the Spanish waters can have multiple causes for the different meadows ranging from input of sewage to burial or erosion derived from construction work along the coast and large-scale government programmes to reclaim beaches. There must be, however, more elusive causes as well, for some of the meadows in undeveloped areas showed evidence of decline (e.g. Rodalquilar), suggesting an influence of non-point sources of disturbance such as man-induced and natural changes in sea level and sediment balances.

The conclusion of the existence of a widespread decline of Posidonia oceanica must be, however, qualified, given the sources of uncertainty in our analysis 
(e.g. only a relatively small area of the meadow was sampled). Yet, we caution the reader that our evaluation was also based on statistical analyses designed to avoid Type 1 error, at the expense of increasing the likelihood of Type 2 error (i.e. claiming that a meadow is in good status when it was indeed in decline). Moreover, recent (1994-1995) visits to the meadows studied do demonstrate the presence of this type of error in our assessment, for some meadows had disappeared well before the time span predicted from our analyses. Given the substantial decimation already experienced by $P$. oceanica meadows in the NW Mediterranean, we suggest, in the light of our results and based on the experience of other European coastlines from which seagrasses have disappeared (much of the Wadden Sea), that managers responsible for the NW Mediterranean coast should consider $P$. oceanica meadows as a declining ecosystem, and adopi efficient protection strategies to avoid their demise.

Posidonia oceanica is a long-lived, slow-growing species, which will have difficulties responding to the widespread decline rcported here. Maintenance and recovery of $P$. oceanica beds depend on rhizome growth and sexual reproduction. $P$. oceanica ranks amongst the species with the slowest rhizome extension rate (about 1 to $6 \mathrm{~cm} \mathrm{yr}^{-1}$; Table 3), and the lowest allocation to sexual reproduction. Examination of the numerous shoots collected for the presence of remains of flower peduncles (cf. Pergent \& PergentMartini 1991) showed these to be present only in 4 of the 29 meadows. Flowering of $P$. oceanica is rare (Caye \& Meinesz 1984, Mazzella et al. 1984, Buia \& Mazzella 1991) when compared to other seagrass species (Gallegos et al. 1992). Moreover, successful sexual reproduction requires seedling establishment, which is also an extremely rare phenomenon in $P$. oceanica, except for a few areas and years, such as the southern Italian coast (Buia \& Mazzella 1991), or the NW Mediterranean in the fall of 1994 when summer surface temperatures reached a record maximum on the Spanish Mediterranean coast (C. M. Duarte unpubl. data, E. Ballesteros unpubl. obs.). Hence, recolonisation of $P$. oceanica is bound to occur very slowly, and models based on its rhizome growth rate and reported patch formation rates (i.e. 0.0003 patches $\mathrm{m}^{-2} \mathrm{yr}^{-1}$; Meinesz \& Lefevre 1984) predict recovery times on the order of centuries (Duarte 1995). These predictions, however, apply to a scenario where the sources of disturbance have been eliminated, which may never occur in the Mediterranean, where anthropogenic pressure on coastal ecosystems is ever increasing (UNEP 1989). P. oceanica meadows lost are, therefore, likely never to become re-established.
Acknowledgements. This study was funded by a grant from the Fundacion Ramón. Areces to C.M.D. J.C. was supported by a scholarship from the C.I.R.I.T. (Generalitat de Catalunya). We are grateful to $S$. Enríquez for field assistance and useful comments on the manuscript. We also thank $\mathrm{G}$. Duarte and S. Agustí for field and laboratory assistance, J. Cebrián and $H$. Vallès for hospitality, and the Direcció General de Parcs of the Generalitat Valenciana for providing access to their facilities in Calp

\section{LITERATURE CITED}

Alcoverro T, Duarte CM, Romero J (1995) Annual growth dynamics of Posidonia oceanica: contribution of largescale versus local factors to seasonality. Mar Ecol Prog Ser 120:203-210

Ardizzone GD, Pelusi P (1984) Yield and damage evaluation of bottom trawling on Posidonia meadows. In: Boudouresque CF, Jeudy de Grissac A, Olivier J (eds) International Workshop Posidonia oceanica beds. GIS Posidonie Publ, Marseille 1:63-72

Benedite V, Torres J, Giner IM. Esteban JL. Capaccioni R, Garcia-Carrascosa AM (1990) Distribution and preliminary evaluation of the status of the Posidonia oceanica on the coast of the Gulf of Valencia (Spain, Western Mediterranean). Rapp Comm Int Mer Médit 32:8

Blanc JJ, Jeudy de Grissac A (1984) Erosions sous-mannes des herbiers à Posidonia oceanica (Méditerranée). In: Boudouresque CF, Jeudy de Grissac A, Olivier J (eds) International Workshop Posidonia oceanica beds. GIS Posidonie Publ, Marseille 1:23-28

Bourcier M (1989) Regression des herbiers à Posidonia oceanica (L.) Delile, a l'Est de Marseille, sous l'action conjugeé des activités humaines et des modifications climatiques. In: Boudouresque CF, Meinesz A, Fresi E, Gravez V (eds) International Workshop on Posidonia beds. GIS Posidonie Publ, Marseille 2:287-292

Buia MC, Mazzella L (1991) Reproductive phenology of the Mediterranean seagrasses Posidonia oceanica (L.) Delile, Cymodocea nodosa (Ucria) Aschers., and Zostera nolti Hornem. Aquat Bot 40:343-362

Cayé G, Meinesz A (1984) Observations sur la floraison et la fructification de Posidonia oceanica dans la Baie de Villefranche et en Corse du Sud. In: Boudouresque CF, Jeudy de Grissac A. Olivier J (eds) International Workshop Posidonia oceanica beds. GIS Posidonie Publ., Marseille 1. 193-201

Cebrián J, Marbà N, Duarte CM (1995) Estimating leaf age of the seagrass Posidonia oceanica (L.) Delile using the plastochron interval index. Aquat Bot 49:59-65

den Hartog C (1970) Seagrasses of the world. North Holland Publ., Amsterdam

Duarte CM (1991) Allometric scaling of seagrass form and productivity. Mar Ecol Prog Ser 77:289-300.

Duarte CM (1995) Submerged aquatic vegetation in relation to different nutrient regimes. Ophelia 41:87-112

Duarte CM, Marbà N, Agawin N, Cebrián J, Enríquez $S$, Fortes MD, Gallegos ME, Merino M, Olesen B, SandJensen K, Uri J, Vermat J (1994) Reconstruction of seagrass dynamics: age determinations and associated tools for the seagrass ecologist. Mar Ecol Prog Ser 107:195-209

Duarte CM, Sand-Jensen K (1990) Seagrass colonization: biomass development and shoot demography in Cymodocea nodosa patches. Mar Ecol Prog Ser 67:97-103

Durako MJ (1994) Seagrass die-off in Florida Bay (USA): changes in shoot demographic characteristics and popula- 
tion dynamics in Thalassia testudinum. Mar Ecol Prog Ser 110:59-66

Eleuterious LN (1987) Seagrass ecology along the coasts of Alabama, Louisiana, and Mississippi. Fla Mar Res Publ 42: $11-24$

Erickson RO, Michelini FJ (1957) The plastochron index. Am $J$ Bot 44:297-305

Gallegos ME, Merino M, Marbà N, Duarte CM (1992) Flowering of Thalassia testudinum Banks ex König in the Mexican Caribbean: age-dependence and interannual variability. Aquat Bot 43:249-255

Gallegos ME, Merino M. Marbà N, Duarte CM (1993) Biomass and dynamics of Thalassia testudinum in the Mexican Caribbean: elucidating rhizome growth. Mar Ecol Prog Ser 95:185-192

Gallegos ME, Merino M, Rodríguez A, Marbà N, Duarte CM (1994) Growth patterns and demography of pioneer Caribbean seagrasses Halodule wrightii and Syringodium filiforme. Mar Ecol Prog Ser 109:99-104

García-Raso JE, Luque AA, Templado J, Salas C, Mergueta E, Moreno D. Calvo M (1992) Fauna y floras marinas del Parque Natural de Cabro de Gata-Nijar Published by the authors, Madrid

Hopkins TS (1985) Physics of the sea. In: Margalef R (ed) Western Mediterranean. Pergamon Press, Oxford, $p$ $100-125$

Lautensach H (1967) Geografia de España y Portugal. VicensVives, Barcelona

Marbà N, Cebrián J, Enríquez S, Duarte CM (1996) Growth patterns of Western Mediterranean seagrasses: speciesspecific responses to seasonal forcing. Mar Ecol Prog Ser 133:203-215

Mazzella L, Gambi MC, Russo GF, Buia MC (1984) Deep flowerng and fruiting of Posidonia oceanica beds around Island of Ischia (Gulf of Naples, Italy). In: Boudouresque

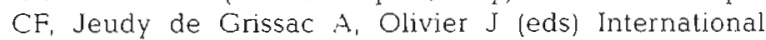
Workshop Posidonia oceanica beds. GIS Posidonie Publ, Marseille 1:203-209

Meinesz A, Lefevre JR (1984) Régéneration d'un herbier de Posidonia oceanica quarante années après sa destruction par une bombe dans la rade de Villefranche (A.lpes-Maritimes, France). In: Boudouresque CF, Jeudy de Grissac A, Olivier J (eds) International Workshop Posidonia oceanica beds. GIS Posidonie Publ, Marseille 1:39-44

Perès J (1984) La regression des herbiers à Posidonia oceanica. In: Boudouresque CF, Jeudy de Grissac A, Olivier J (eds) International Workshop Posidonia oceanica beds. GIS Posidonie Publ, Marseille 1:445-454

This article was presented by G. W. Thayer (Senior Editorial Advisor), Beaufort, North Carolina, USA
Pergent G (1990) Evaluation of Posidonia oceanica primary production using lepidochronological analysis: preliminary results. Rapp Comm int Mer Médit 32:6

Pergent G, Pergent-Martini C (1991) Some applications of lepidochronological analysis in the seagrass Posidonia oceanica. Bot Mar 33:299-310

Picard J (1965) Recherches qualitatives sur les biocenoses marines des substrats meubles dragables de la région marseillaise. Rec Trav Stn Mar Endoume Fac Scu Mars 52: $3-160$

Porcher M (1984) Impact des mouillages forains sur les herbiers à Posidonia oceanica. In: Boudouresque CF, Jeudy de Grissac A, Olivier $J$ (eds) International Workshop Posidonia oceanica beds. GIS Posidonie Publ. Marsenlle 1: $145-148$

Romero-Martinego J (1985) Estudio ecológico de las fanerógamas de la costa Catalana: producción primaria de Posidonia oceanica (L.) Delile en las Islas Medas. PhD thesis, Universidad de Barcelona

Sanchez-Lizaso JL, Guillen-Nieto JE, Ramos Esplà AA (1990) The regression of Posidonia oceanica meadows in El Campello (Spain). Rapp Comm Int Mer Médit 32:7

Semoroud R, Mezegrave S, Soltane L (1990) Etude lépidochronologique de Posidonia oceanica dans la région d'Alger (Algérie): données préliminaires. Rapp Comm Int Mer Médit 32:15

Sheil D, Burslem DFRP, Alder D (1995) The interpretation and misinterpretation of mortality rate measures. J Ecol 83: $331-333$

Temez-Peláez JR (1993) Una mayor perspectiva histórica útil para la planificacıón hidrológica. Revista de Obras Públicas 3324:37-44

Templado J (1984) Las prederas de Posidonia oceanica en el sureste español y su biocenosis. In: Boudouresque CF, Jeudy de Grissac A, Olivier J (eds) International Workshop Posidonia oceanica beds. GIS Posidonie Publ. Marseille 1:159-172

Torres J, Giner LM, Benedito V, Esteban JL, Capaccioni R, Garcia-Carrascosa AM (1990a) Distribution and preliminary evaluation of the state of the Posidonia oceanica meadows on the coasts of Alicante (Spain, Western Mediterranean). Rapp Comm Int Mer Médit 32:9

UNEP (United Nations Environment Programme) (1989) State of the Mediterranean marine environment. MAP Technical Reports Series 28, Athens, p 34-49

Zavodnik N, Jaklin A (1990) Long-term changes in the Northern Adriatic marine phanerogam beds. Rapp Comm Int Mer Médit 32:15

Manuscript first received: January 25, 1995

Revised version accepted: February 15, 1996 